\title{
Profil Pohon pada jenis Litsea spp. di Hutan Pendidikan
}

\author{
(The Profile of Tree Litsea spp. in The Education Forest) \\ Fajriansyah $^{1 *}$, Rita Diana ${ }^{2}, \&$ Paulus Matius ${ }^{2}$ \\ ${ }^{1}$ Mahasiswa Jurusan Kehutanan, Fakultas Kehutanan, Universitas Mulawarman, Samarinda, 97233 \\ 2 Jurusan Kehutanan, Fakultas Kehutanan, Universitas Mulawarman, Samarinda, 97233
}

Email : fajrif78@gmail.com

\begin{abstract}
The purpose of this study was to determine the morphological condition of Litsea spp. Including the condition of the trunk, branching, the canopy, especially the relationship between the diameter of the trunk and the total height of the tree, the diameter of the trunk to the width of the canopy, and the total height of the tree to the width of the canopy in the Education Forest, Faculty of Forestry, Mulawarman University Samarinda East Kalimantan. The method of this study was purposive sampling method, which looking for Litsea spp. As the object of research as many as 33 trees and seven types of Litsea spp. The tree parameters measured were diameter, branch free, tree height, and canopy width. The results showed that $57.4 \%$ of the trees were healthy. The results of the tree's overall data analysis showed that the regression coefficient value between diameter and height, and diameter with canopy width have a moderate correlation value, this indicated that the diameter of the tree has no relationship to tree height and canopy width in Litsea spp. And similar conditions also occurred in the correlation between the height of the tree, which also has a moderate correlation, so it indicated the tree's height does not affect the width of the canopy.
\end{abstract}

KEYWORDS: Litsea spp., tree health, HPFU.

\section{INTISARI}

Tujuan penelitian ini untuk mengetahui kondisi morfologis pohon Litsea spp. termasuk diantaranya kondisi batang, kondisi percabangan, kondisi tajuk, khususnya hubungan antara diameter batang dan tinggi total pohon, diameter batang dengan lebar tajuk, dan tinggi total pohon dengan lebar tajuk, di Hutan Pendidikan Fahutan Unmul Samarinda Kalimantan Timur. Metode yang digunakan adalah metode purposive sampling, mencari pohon Litsea spp. sebagai objek penelitian sebanyak 33 pohon dan 7 jenis Litsea spp. Parameter pohon yang diukur adalah diameter, bebas cabang, tinggi pohon, dan lebar tajuk. Dari hasil penelitian menunjukkan bahwa $57,4 \%$ pohon sehat. Hasil analisis data keseluruhan pohon nilai koefisien regresi antara diameter dengan tinggi, dan diameter dengan lebar tajuk memiliki nilai korelasi sedang, hal ini mengindikasikan bahwa diameter pohon tidak memiliki hubungan terhadap tinggi pohon dan lebar tajuk pada pohon Litsea spp. Kondisi serupa juga terjadi pada hubungan kolerasi antara tinggi pohon yang juga memiliki hubungan kolerasi sedang sehingga mengindikasikan tinggi pohon tidak mempengaruhi lebar tajuk.

KATA KUNCI: Litsea spp., kesehatan pohon, HPFU

\section{PENDAHULUAN}

Keanekaragaman hayati (biodiversitas) adalah keanekaragaman berbagai macam bentuk kehidupan serta plasma nutfah yang terkandung di dalamnya dan keanekaragaman sistem ekologi di mana mereka hidup. Keanekaragaman hayati sangatlah penting bagi seluruh kehidupan di bumi, baik untuk pemenuhan kebutuhan sandang, pangan, papan, obat-obatan, dan wahana 
Profil Pohon pada jenis Litsea spp. di Hutan Pendidikan

(Fajriansyah", Rita Diana, \& Paulus Matius)

wisata, maupun untuk mengatur proses ekologi sistem penyangga kehidupan antara lain penghasil oksigen, pencegahan pencemaran udara dan air, mencegah banjir dan longsor (Putri, et al. 2015).

Indonesia merupakan salah satu negara dengan tingkat keanekaragaman hayati yang tinggi (mega-biodiversity) (Park et al. 2010), diantaranya tercermin dari jumlah spesies tumbuhan dunia yang terdapat di Indonesia yaitu sebesar 11\%, walaupun luas daratan Indonesia hanya 1,3\% dari luas daratan permukaan bumi (Rocky et al. 2008; Roswati 2015). Keanekaragaman hayati di Indonesia kekayaan dari hutan hujan tropis yang terhampar luas.

Litsea adalah genus yang memiliki 318 spesies pohon (Cronquist, 1981;Kostermans,1957). Tumbuhan genus Litsea memiliki manfaat diantaranya sebagai pakan ternak, bahan bangunan, tanaman pelindung, tanaman hias, bahan baku industry, penghasil minyak atsiri dan bahan pengobatan (Kuspradini dkk, 2018).

Hutan hujan tropis merupakan vegetasi yang paling kaya, baik dalam arti jumlah jenis makhluk hidup yang membentuknya, maupun dalam tingginya nilai sumberdaya lahan (tanah, air, cahaya matahari) yang dimilikinya. Hutan dataran rendah ini didominasi oleh pepohonan besar yang membentuk tajuk berlapis-lapis (layering), sekurang-kurangnya tinggi tajuk teratas rata-rata adalah $45 \mathrm{~m}$ (paling tinggi dibandingkan rata-rata hutan lainnya), rapat, dan hijau sepanjang tahun (Whitmore, 1984).

Menurut Yunita (2016) salah satu peranan hutan sebagai fungsi perlindungan dalam konteks perubahan iklim adalah sebagai penyimpan karbon/rosot karbon (carbon sink) yaitu vegetasi hidup di dalam hutan melalui proses fotosintesis mampu menyerap gas $\mathrm{CO}_{2}$ dan menyimpannya dalam bentuk biomassa. Di samping pengendalian terhadap laju deforestasi, upaya mitigasi perubahan iklim dilakukan untuk mengedepankan fungsi hutan sebagai carbon sink, yaitu meningkatkan produktivitas kemampuan hutan dalam mereduksi emisi $\mathrm{CO}_{2}$ di atmosfer dan menyimpannya sebagai cadangan karbon (carbon stock).

Hutan Pendidikan merupakan wahana bagi masyarakat khususnya pelajar, mahasiswa dan peneliti untuk mempelajari hutan dan hubungan timbal balik antar komponen ekosistemnya (Badan Pengelola Hutan Pendidikan, 2018). Data tentang profil pohon yang menyusun hutan pendidikan merupakan informasi dasar yang diperlukan untuk pendidikan maupun pengembangan pengelolaan hutan pendidikan.

Informasi penting yang mutlak ada dalam rangka pengelolaan hutan pendidikan adalah keanekaragaman hayati yang ada di dalamnya. Berkaitan dengan ini, profil pohon dapat dijadikan parameter keanekaragaman hayati di suatu ekosistem. Pohon merupakan komponen yang mendominasi pada suatu hutan, yang berperan sebagai organisme produsen dan habitat dari berbagai jenis burung dan hewan lainnya. Pohon menggunakan energi radiasi matahari dalam 
proses fotosintesis, sehingga mampu mengasimilasi $\mathrm{CO}_{2}$ dan $\mathrm{H}_{2} \mathrm{O}$ menghasilkan energi kimia yang tersimpan dalam karbohidrat dan mengeluarkan oksigen yang kemudian dimanfaatkan oleh semua makhluk hidup di dalam proses pernapasan. Keanekaragaman pohon dapat digunakan untuk menyatakan struktur komunitas. Keanekaragaman jenis pohon juga dapat digunakan untuk mengukur stabilitas komunitas, yaitu kemampuan suatu komunitas untuk menjaga dirinya tetap stabil meskipun ada gangguan terhadap komponen-komponennya (Indriyanto, 2006)

Informasi mengenai profil pohon Litsea spp. di KPHP Hutan Pendidikan Fahutan Unmul saat ini sangat terbatas dan kurang terdokumentasi dengan baik. Penelitian tentang profil pohon Litsea spp. di KPHP Hutan Pendidikan Fahutan Unmul ini masih sangat diperlukan untuk memperbarui informasi yang sudah ada dan menambah informasi yang belum terdokumentasikan.

Berdasarkan uraian di atas, maka perlu dilakukan penelitian dengan profil pohon pada jenis Litsea spp. di KPHP Hutan Pendidikan Fahutan Unmul.

\section{METODE PENELITIAN}

\section{Lokasi dan Waktu Penelitian}

Penelitian ini dilaksanakan pada Hutan Pendidikan Fakultas Kehutanan Universitas Mulawarman. Waktu yang diperlukan dalam penelitian ini kurang lebih selama 6 bulan efektif, meliputi: studi pustaka, orientasi lapangan, pengumpulan data serta analisis data.

\section{Alat dan Bahan Metode}

Peralatan yang digunakan dalam penelitian ini antara lain: GPS, kompas, Phiband, Klinometer, Tongkat $4 \mathrm{~m}$, Meteran, Parang, Pita survey, Kamera, Alat tulis, dan Laptop. Sedangkan bahan yang digunakan dalam penelitian ini antara lain: Peta lokasi penelitian Tallysheet.

\section{Prosedur Penelitian}

\section{Studi Pustaka}

Studi pustaka diperlukan untuk memperoleh informasi yang digunakan sebagai bahan masukan dan perbandingan dalam menunjang penelitian. Studi pustaka diperoleh melalui bukubuku, laporan-laporan, serta skripsi-skripsi yang berhubungan dengan penelitian ini.

\section{Orientasi Lapangan}

Kegiatan orientasi lapangan ini dilakukan untuk pengecekkan kembali lokasi penelitian, untuk memperoleh informasi yang lengkap mengenai kondisi umum lokasi yang akan diteliti dalam membantu penentuan pola penelitian yang digunakan. 
Profil Pohon pada jenis Litsea spp. di Hutan Pendidikan

(Fajriansyah", Rita Diana, \& Paulus Matius)

\section{Metode Pengambilan Data}

\section{Penentuan Pola Penelitian}

Pada penelitian ini dilaksanakan dengan purposive sampling pohon Litsea sp. sebagai objek untuk penelitian yang dilakukan secara purposif sampling yaitu memilih dengan sengaja pohon sebanyak 33 pohon dengan kriteria profil pohon adalah gambaran tentang kondisi dari satu jenis pohon yang biasanya berhubungan dengan morfologi dari pohon tersebut. Pada setiap pohon yang ditemukan dilakukan pendataan dan pengukuran serta penentuan titik koordinat. Selanjutnya memberikan tanda atau label nomor pada pohon yang telah dilakukan pendataan dan pengukuran untuk mencegah terjadinya pendataan ulang.

\section{Pengambilan Data}

Kegiatan pengambilan data diperoleh melalui pengukuran dan pengamatan secara langsung di lapangan yang meliputi: Letak/posisi pohon Litsea spp. (titik koordinat); Fisik pohon Litsea spp. (diameter batang, tinggi total, tinggi bebas cabang dan diameter tajuk); Kondisi dan bentuk tajuk pohon Litsea spp., Kondisi batang pohon Litsea spp. (baik atau cacat);

\section{Analisis Data}

Hasil pengukuran dianalisis menggunakan pengujian hipotesis asosiatif yang merupakan dugaan adanya hubungan antara variable dalam populasi, melalui data hubungan variable dalam sampel (Sugiyono, 2010).

\section{HASIL DAN PEMBAHASAN}

\section{Kondisi Pohon Litsea spp. Di Hutan Pendidikan Fahutan Unmul}

Hasil pengukuran kondisi pohon, jenis Litsea spp. yang meliputi diameter batang, tinggi total, dan lebar tajuk terbesar dan yang terkecil sebagaimana terlihat pada Tabel 1.

Tabel 1. Perbandingan hasil pengukuran diameter batang, tinggi total pohon, dan lebar tajuk terbesar dan terkecil pada tanaman Litsea spp.

\begin{tabular}{lccc}
\hline & Diameter Batang $\mathbf{( c m )}$ & Tinggi Total (m) & Lebar Tajuk (m) \\
\hline Maksimum & 44,5 & 29,33 & 10,50 \\
Minimum & 10,1 & 7,8 & 0,63 \\
Rata-Rata & 26,61 & 15,87 & 5,27 \\
\hline
\end{tabular}

Pada Tabel 1 menunjukkan bahwa fisik pada pohon Litsea spp. seperti diameter batang, tinggi total, dan lebar tajuk cukup bervariasi. Bervariasinya kondisi fisik pohon Litsea spp. tersebut, antara lain disebabkan oleh beberapa faktor yaitu karakter masing-masing jenis tempat tumbuh seperti, hara, mineral, tanah, air, cahaya, dan ruang hidup. Persaingan pada pohon ini menyebabkan terbentuknya susunan komunitas yang khas, baik bentuk, macam, jumlah, dan jenis jumlah individunya disesuaikan dengan tempat tumbuhnya (Diana dkk,2011). 


\section{Nilai Parameter Pohon Litsea spp.}

Koefisien korelasi dan parameter antara diameter batang dengan tinggi total pohon, diameter batang dengan lebar tajuk, dan tinggi total pohon dengan lebar tajuk

Berdasarkan hasil penelitian yang telah dilakukan diketahui nilai korelasi dan koefisien regresi untuk mengetahui hubungan antara diameter batang pohon dengan tinggi total pohon, diameter batang dengan lebar tajuk, dan tinggi total pohon dan lebar tajuk dapat dilihat pada tabel berikut:

Tabel 2. Nilai korelasi dan koefisien regresi antara parameter diameter batang pohon dengan tinggi total pohon, diameter batang dengan lebar tajuk, dan tinggi total pohon dengan lebar tajuk.

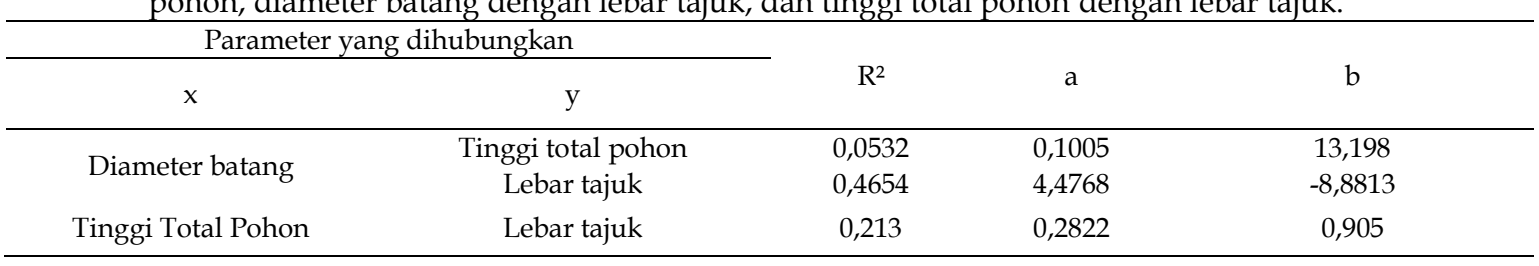

Tabel 2 menunjukkan bahwa hubungan antara diameter batang $(\mathrm{x})$ dengan tinggi total pohon (y) dinyatakakan dengan nilai korelasi $\left(R^{2}\right)$ 0,0532, kemudian diameter batang dengan lebar tajuk dengan nilai korelasi $\left(R^{2}\right)$ 0,4654 yang artinya bahwa hubungan antara diameter batang dan pohon dengan tinggi total pohon dan diameter batang pohon dengan lebar tajuk, kedua variabel tersebut bernilai sedang. Hal ini berarti bahwa semakin besar diameter batang pohon tidak selalu berkaitan terhadap pertumbuhan tinggi total dan lebar tajuk pohon. Dari hubungan diameter batang pohon dan tinggi total pohon tersebut dapat dilihat bahwa $a=0,1005$ dan nilai $b=13,198$, yang berarti menunjukkan pada garis linear kearah yang positif hal ini dikarenakan nilai $b$ menunjukkan nilai positif $(+)$.

Hubungan diameter batang pohon dan lebar tajuk tersebut dapat dilihat bahwa nilai $\mathrm{a}=$ 4,4768 , dan nilai $b=-8,8813$, hal ini juga berarti menunjukkan pada garis linear kearah yang positif, hal ini dikarenakan nilai $\mathrm{b}$ menunjukkan nilai positif $(+)$. Sedangkan hubungan tinggi total pohon dengan lebar tajuk tersebut. Kemudian pohon dan lebar tajuk tersebut dapat dilihat bahwa nilai $\mathrm{a}=0,2822$, dan nilai $\mathrm{b}=0,905$, hal ini juga berarti menunjukkan pada garis linear kearah yang positif, hal ini dikarenakan nilai b menunjukkan nilai positif (+).

Hubungan diameter batang dengan tinggi total pohon, diameter batang dengan lebar tajuk, dan tinggi total pohon dengan lebar tajuk

Nilai korelasi dan regresi pada Tabel 2 menunjukkan bahwa hubungan diameter batang dengan tinggi total pohon, kemudian diameter batang dengan lebar tajuk, dan tinggi total pohon dengan lebar tajuk disajikan pada Gambar 1. 
Profil Pohon pada jenis Litsea spp. di Hutan Pendidikan

(Fajriansyah", Rita Diana, \& Paulus Matius)

\section{Hubungan diameter batang dengan tinggi total pohon}

Berdasarkan hasil penelitian yang telah dilakukan, dapat diketahui hubungan diameter batang dengan tinggi total pohon pada lokasi penelitian. Untuk lebih jelasnya dapat dilihat pada Gambar 1 .

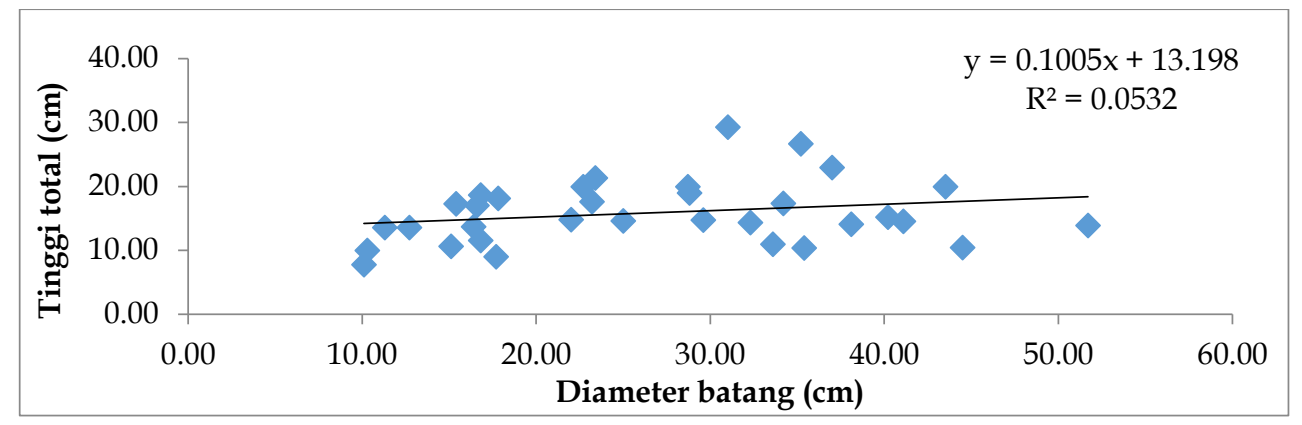

Gambar 1. Grafik hubungan antara diameter batang dengan tinggi total pohon.

Gambar 1 menunjukkan bentuk persamaan antara hubungan diameter batang dengan tinggi total pohon yaitu $y=0,1005 x+13,198$. Hal ini dapat dilihat bahwa nilai $b=0,1005$ menunjukkan nilai positif $(+)$ dimana terjadi hubungan yang positif. Sedangkan nilai a $=+13,198$ yang berarti menunjukkan nilai awal perhitungan diameter batang. Nilai koefisien korelasi $\left(R^{2}\right)=$ 0,0532, artinya nilai ini memiliki hubungan fungsional kedua variabel tersebut bernilai sedang.

Penelitian ini sama halnya dengan penelitian yang dilakukan oleh Diana dkk, (2011) pada pohon jenis Scorodocarpus borneensis Becc. dan Susilawati (2007) pada Durio oxleyanus Griff.) Pohon yang berbeda tetapi sama - sama menyatakan bahwa diameter batang dengan tinggi total pohon diperoleh nilai korelasi yang positif namun dalam kategori sedang. Hal ini menunjukkan bahwa semakin besar diameter batang tidak selalu berkaitan dengan pertumbuhan tinggi pohon, dengan kata lain parameter diameter batang tidak untuk dijadikan indikasi yang kuat dalam memperkirakan pertumbuhan tinggi pohon.

\section{Hubungan Diameter Batang dan Lebar Tajuk}

Berdasarkan hasil penelitian yang telah dilakukan, dapat diketahui hubungan diameter batang dengan lebar tajuk pada lokasi penelitian. Untuk lebih jelasnya dapat dilihat pada Gambar. 4.2 berikut; 


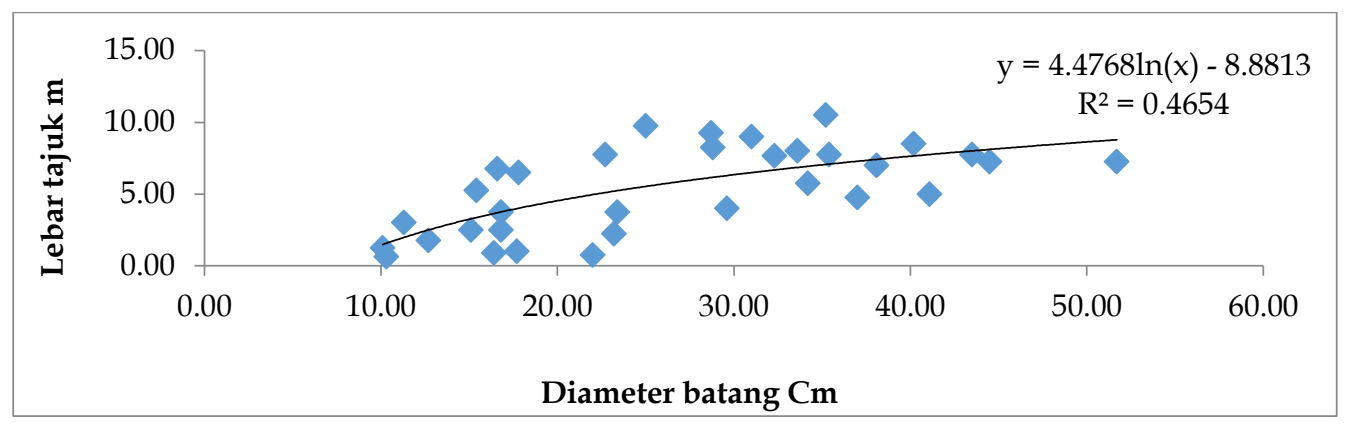

Gambar 2. Grafik hubungan antara diameter batang dengan lebar tajuk.

Gambar 2 menunjukkan bentuk persamaan regresi hubungan antara diameter batang dengan lebar tajuk yaitu $y=4,4768 x-8,8813$. Dalam hal ini berarti, nilai $b=4,4768 x$ menunjukkan nilai positif maka terjadi hubungan yang positif, sedangkan nilai a $=-8,8813$ yang berarti menunjukkan nilai awal perhitungan diameter batang. Nilai koefisien korelasi $\left(R^{2}\right)=0,4654$, artinya nilai ini memiliki hubungan fungsional kedua variabel tersebut bernilai sedang.

Hubungan nilai korelasi dan koefisien regresi antara parameter diameter batang dengan lebar tajuk memiliki nilai korelasi positif dan bernilai sedang. Dengan kata lain penelitian ini sejalan dengan penelitian yang dilakukan oleh Diana dkk (2011) yang dimana penelitian jenis Scorodocarpus borneensis Becc. yang menyatakan hubungan nilai korelasi dan koefisien regresi antara parameter diameter batang dengan lebar tajuk memiliki hubungan positif namun rendah dengan nilai koleratif $\left(R^{2}\right)=0,39$ dengan bentuk persamaan adalah y $=5,05+0,06 x$. Hal ini menunjukkan bahwa semakin besar diameter batang tidak selalu berkaitan dengan lebar tajuk, dengan kata lain parameter diameter batang tidak dapat dijadikan indikasi yang kuat dalam memperkirakan pertumbuhan lebar tajuk pohon.

\section{Hubungan Tinggi Total Pohon dan Lebar Tajuk}

Berdasarkan hasil penelitian yang telah dilakukan, dapat diketahui hubungan tinggi total pohon dan lebar tajuk pada lokasi penelitian. Gambar 3 menunjukkan bentuk persamaan regresi antara hubungan tinggi total pohon dengan lebar tajuk adalah $y=0,2822 x+0,905$, dimana pada persamaan ini menunjukkan nilai $b=0,2822 x$ adalah nilai positif, artinya semakin besar nilai tinggi total pohon maka semakin besar pula nilai lebar tajuk. Sedangkan nilai $a=0,905$ yang berarti menunjukkan nilai awal perhitungan lebar tajuk. 


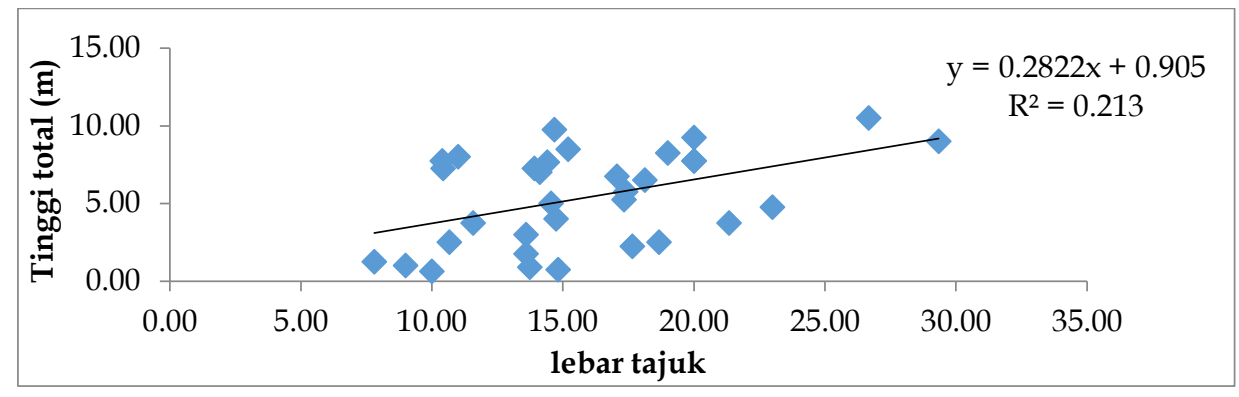

Gambar 3. Grafik Hubungan Tinggi Total dengan Lebar Tajuk

Nilai koefisien korelasi $\left(R^{2}\right)=0,213$ yang berarti hubungan antara parameter tinggi total pohon dengan lebar tajuk diperoleh korelasi positif namun hubungannya rendah. Dengan kata lain berarti semakin besar nilai tinggi total pohon tidak berkaitan dengan lebar tajuk. Hal ini sejalan dengan penelitian yang dilakukan oleh Diana dkk (2011) dimana penelitian Scorodocarpus borneensis Becc. merupakan objek penelitian, namun persamaan korelasi yang diperoleh yaitu y $=$ $0,14 x+5,51$, dimana nilai $b=0,14$ dan nilai $a=5,51$ yang menunjukkan nilai awal perhitungan, sedangkan nilai korelasi $\mathrm{R}^{2}=0,31$ yang menunjukkan hubungan tersebut rendah. Parameter ini menunjukkan bahwa tinggi total pohon tidak dapat dijadikan sebagai indikasi yang kuat dalam memperkirakan pertambahan lebar tajuk pohon.

\section{Koefisien Korelasi Antara Parameter Yang Diukur Pada Pohon Sehat}

Berdasarkan hasil penelitian di lapangan, dengan jenis Litsea spp. sebagai objek penelitian yang dihubungkan antara diameter batang dengan tinggi total pohon, diameter batang dengan lebar tajuk, dan tinggi total pohon dengan lebar tajuk pada pohon sehat, dapat dilihat sebagai berikut :

\section{Koefisien Korelasi dan Persamaan Regresi pada Pohon Sehat}

Berikut adalah nilai korelasi dan koefisien regresi untuk mengetahui hubungan antara diameter batang pohon dengan tinggi total pohon, diameter batang dengan lebar tajuk, dan tinggi total pohon pada pohon sehat dapat dilihat pada Tabel 3 berikut :

Tabel 3. Kondisi pada pohon sehat Litsea spp.

\begin{tabular}{cccc}
\hline No pohon & Diameter Batang $(\mathrm{cm})$ & Tinggi total $(\mathrm{m})$ & Lebar tajuk $(\mathrm{m})$ \\
\hline 2 & 23,2 & 17,65 & 2,23 \\
5 & 41,1 & 13,91 & 5 \\
6 & 51,7 & 10,4 & 7,25 \\
7 & 34,2 & 20 & 5,75 \\
8 & 29,6 & 23 & 4 \\
9 & 15,1 & 11 & 2,5 \\
11 & 35,4 & 26,67 & 7,75 \\
15 & 10,1 & 7,8 & 1,25
\end{tabular}




\begin{tabular}{cccc}
\hline No pohon & Diameter Batang $(\mathrm{cm})$ & Tinggi total $(\mathrm{m})$ & Lebar tajuk $(\mathrm{m})$ \\
\hline 16 & 22,7 & 14,81 & 7,75 \\
17 & 28,7 & 18,67 & 9,25 \\
18 & 28,8 & 11,58 & 8,25 \\
20 & 16,8 & 17,07 & 3,75 \\
23 & 32,3 & & 7,67 \\
24 & 43,5 & 20 & 7,75 \\
25 & 37 & 19 & 4,75 \\
26 & 33,6 & 13,6 & 8 \\
27 & 40,2 & 13,6 & 8,5 \\
29 & 12,7 & 17,4 & 1,75 \\
33 & 23,4 & 10,67 & 3,75 \\
\hline
\end{tabular}

Tabel 3 terdapat 19 pohon yang termasuk pohon sehat yang memiliki diameter batang, tinggi total, lebar tajuk dan intesitas cahaya yang bervariasi. Diameter batang terbesar terdapat pada pohon nomor 6 yaitu 51,7 cm kemudian diameter batang terkecil pada pohon nomor 15 yaitu $10,1 \mathrm{~cm}$. Tinggi total pohon tertinggi pada nomor 11 yaitu $26,67 \mathrm{~m}$. Kemudian total tinggi terendah pada pohon nomor 15 yaitu 7,8 m. Sedangkan pada lebar tajuk terbesar terdapat paada pohon nomor 17 yaitu 9,25 m, kemudian pada lebar terkecil terdapat pada pohon nomor 15 yaitu 1,25 m. Dari data dilapangan tersebut dapat dijadikan parameter untuk mengetahui hubungan antara diameter batang dengan tinggi total pada pohon sehat. Untuk mengetahui hubungan antara diameter batang dengan tinggi total pada pohon sehat dapat dilihat pada Tabel sebagai berikut :

Tabel 4. Nilai korelasi dan Persamaan Regresi antar Parameter Diameter Batang dengan Tinggi Total Pohon, Diameter Batang dengan Lebar Tajuk, dan Total Pohon dengan Lebar Tajuk Pada Pohon Sehat

\begin{tabular}{ccccc}
\hline Parameter yang dihubungkan & \multirow{2}{*}{$\mathrm{R}^{2}$} & $\mathrm{a}$ & $\mathrm{b}$ \\
\cline { 1 - 3 } $\mathrm{x}$ & $\mathrm{y}$ & & & \\
\hline Diameter batang & Tinggi total pohon & 0,0446 & 0,0904 & 13,19 \\
& Lebar tajuk & 0,4396 & 0,1543 & 1,0781 \\
& Lebar tajuk & 0,0271 & 0,0895 & 4,2067 \\
\hline
\end{tabular}

Tabel 4 terlihat bahwa hubungan antara diameter batang $(\mathrm{x})$ dengan tinggi total pohon $(\mathrm{y})$ memiliki nilai koefisien korelasi sebesar $\left(R^{2}\right)=0,0446$ dari hubungan tersebut nilai a $=0,0904$ dan nilai $b=13,19$ yang berarti menunjukkan kedua variabel tersebut bernilai positif hal ini dikarenakan nilai b menunjukkan nilai positif $(+)$. Selanjutnya hubungan antara diameter batang (x) dengan lebar tajuk (y) memiliki nilai koefisien korelasi sebesar $\left(R^{2}\right)=0,4396$, dari hubungan tersebut juga terlihat nilai $a=0,1543$ dan nilai $b=1,0781$ yang berarti menunjukkan kedua variabel tersebut bernilai positif hal ini dikarenakan nilai b menunjukkan nilai positif (+). Sedangkan hubungan antara tinggi total pohon $(\mathrm{x})$ dengan lebar tajuk $(\mathrm{y})$ memiliki nilai koefisien korelasi 
Profil Pohon pada jenis Litsea spp. di Hutan Pendidikan

(Fajriansyah", Rita Diana, \& Paulus Matius)

sebesar $\left(R^{2}\right)=0,0271$, hal ini menunjukkan bahwa hubungan tersebut juga terlihat nilai a $=0,0895$ dan nilai $b=4,2067$ yang berarti kedua variabel tersebut bernilai positif hal ini dikarenakan nilai $b$ menunjukkan nilai positif $(+)$.

Hubungan Nilai Korelasi dan Persamaan Regresi pada Pohon Sehat.

Nilai korelasi dan koefisien regresi untuk mengetahui hubungan antara diameter batang, lebar tajuk, dan tinggi total pohon dengan lebar tajuk pada pohon sehat dapat dilihat pada Gambar 4.

\section{Hubungan diameter batang dengan tinggi total pohon sehat}

Berdasarkan hasil penelitian yang telah dilakukan, dapat diketahui hubungan diameter batang dengan tinggi total pohon sehat pada lokasi penelitian. Untuk lebih jelasnya dapat dilihat pada Gambar 4 .

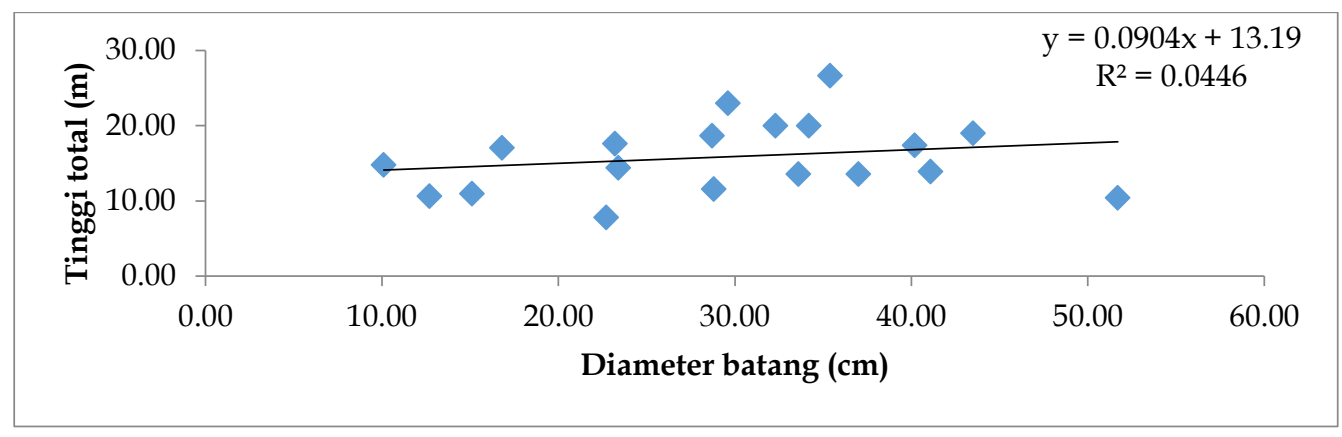

Gambar 4. Grafik hubungan diameter batang dengan tinggi total pohon sehat

Gambar 4 memperlihatkan bentuk persamaan nilai koefisien korelasi sebagai berikut $\mathrm{y}=$ $0,0904 x+13,19$, dalam hal ini berarti nilai $b=0,0904 x$ menunjukkan bahwa terjadi hubungan yang positif, artinya semakin besar diameter batang semakin besar pula tinggi total pohon. Sedangkan nilai $\mathrm{a}=13,19$ yang berarti menunjukkan nilai awal perhitungan diameter batang. Kerataan hubungan antara diameter batang $(\mathrm{x})$ dengan tinggi total $(\mathrm{y})$ dinyatakan dengan nilai korelasi $\left(\mathrm{R}^{2}\right)$ $=0,0446$ dimana hubungan fungsional variabel tersebut sedang.

Hal ini sama dengan penelitian yang dilakukan oleh Diana dkk, (2011) dimana semakin besar diameter batang berkaitan dengan pertumbuhan tinggi total pohon. Dengan kata lain, parameter diameter batang dengan tinggi total pohon sehat dapat dijadikan indikasi yang sangat kuat dalam memprediksikan pertumbuhan tinggi total pohon.

\section{Hubungan diameter batang dengan lebar tajuk pohon sehat}

Berdasarkan hasil penelitian yang telah dilakukan, dapat diketahui hubungan diameter batang dengan lebar tajuk pohon sehat pada lokasi penelitian. Untuk lebih jelasnya dapat dilihat pada Gambar 5 . 


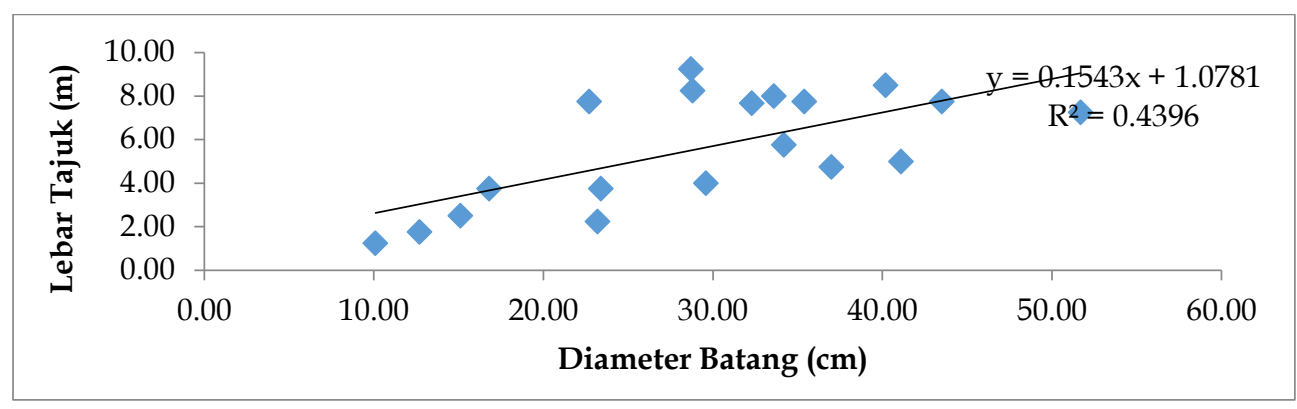

Gambar 5. Grafik hubungan diameter batang dengan lebar tajuk pohon sehat

Gambar 5 memperlihatkan bentuk persamaan nilai koefisien korelasi sebagai berikut y $=$ $0,1543 x+1,0781$, dalam hal ini berarti, nilai $b=0,1543 x$ menunjukkan bahwa terjadi hubungan yang positif, sedangkan nilai a $=1,0781$ yang berarti menunjukkan nilai awal perhitungan diameter batang. Keeratan hubungan antara diameter batang $(\mathrm{x})$ dengan lebar tajuk (y) dinyatakan dengan nilai korelasi $\left(R^{2}\right)=0,4396$ dimana hubungan fungsional variabel tersebut Sedang. Hal ini berarti bahwa semakin besar diameter batang pohon tidak selalu berkaitan dengan lebar tajuk. Dengan kata lain, parameter diameter batang dengan lebar tajuk tidak dapat dijadikan indikasi yang kuat dalam memperkirakan pertumbuhan lebar tajuk.

\section{Hubungan tinggi total dengan lebar tajuk pohon sehat}

Berdasarkan hasil penelitian yang telah dilakukan, dapat diketahui hubungan diameter batang dengan lebar tajuk pohon sehat pada lokasi penelitian. Untuk lebih jelasnya dapat dilihat pada Gambar 6.

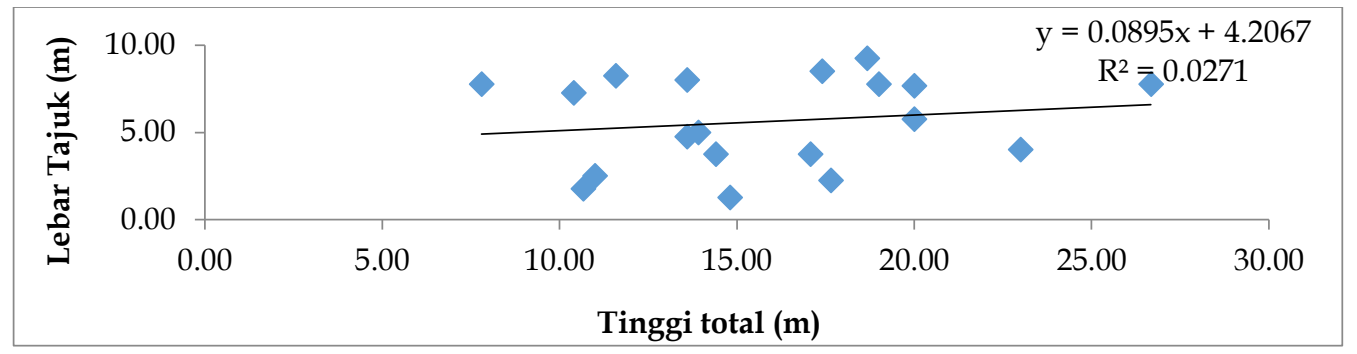

Gambar 6. Grafik hubungan tinngi total pohon dengan lebar tajuk pohon sehat.

Gambar 6 memperlihatkan bentuk persamaan nilai koefisien korelasi sebagai berikut y $=$ 0,0895x $+4,2067$, dalam hal ini berarti, nilai $b=0,0895 x$ menunjukkan bahwa terjadi hubungan yang positif, artinya semakin besar diameter batang semakin besar pula tinggi total pohon. Sedangkan nilai a $=4,2067$ yang berarti menunjukkan nilai awal perhitungan diameter batang . keeratan hubungan antara tinggi total pohon dengan lebar tajuk (y) dimyatakan dengan nilai korelasi $\left(R^{2}\right)=0,0271$ dimana hubungan fungsional variabel tersebut rendah . parameter ini menunjukkan bahwa tinggi total pohon tidak dapat di jadikan sebagai indikasi yang kuat dalam memperkirakan pertambahan lebar tajuk pohon pada pohon sehat. 
Profil Pohon pada jenis Litsea spp. di Hutan Pendidikan

(Fajriansyah", Rita Diana, \& Paulus Matius)

Hal ini dapat dibandingkan berdasarkan tinggi total pohon dan lebar tajuk pada jenis Scorodocarpus borneensis Becc memiliki nilai yang besar dari 8,50 m sampai dengan 20,45 m dan lebar yaitu 6,37 m sampai dengan 10,32 m.

Koefisien Korelasi dan Persamaan Regresi antar Parameter Diameter Batang dengan Tinggi Total Pohon, Diameter Batang dengan Lebar Tajuk,dan Tinggi Total Pohon dengan Lebar Tajuk pada

\section{Pohon Litsea spp.}

Berdasarkan hasil penelitian dilapangan, dengan jenis Litsea Spp. Sebagai objek penelitian yang dihubungkan antara diameter batang dengan tinggi total pohon, diameter batang dengan lebar tajuk, dan tinggi total pohon dengan lebar tajuk pada pohon cacat dapat dilihat sebagai berikut :

\section{Koefisien Korelasi dan Persamaan Regresi pada Pohon Cacat}

Berikut adalah nilai korelasi dan koefisien regresi untuk mengetahui hubungan antara diameter batang pohon dengan tinggi total pohon, diameter batang dengan lebar tajuk, dan tinggi total pohon dengan lebar tajuk pada pohon cacat dapat dilihat pada Tabel 5.

Tabel 5. Kondisi Litsea Spp, pada pohon cacat

\begin{tabular}{cccc}
\hline No Pohon & Diameter batang $(\mathrm{cm})$ & Tinggi Total Pohon $(\mathrm{m})$ & Lebar Tajuk $(\mathrm{m})$ \\
\hline 1 & 16,4 & 13,74 & 0,9 \\
3 & 10,3 & 10 & 0,63 \\
4 & 17,7 & 14,55 & 1 \\
10 & 44,5 & 15,2 & 7,25 \\
12 & 22 & 29,33 & 0,75 \\
13 & 16,6 & 17,33 & 6,75 \\
14 & 17,8 & 21,33 & 6,5 \\
19 & 16,8 & 14,67 & 2,5 \\
21 & 38,1 & 18,13 & 7 \\
22 & 25 & 20 & 9,75 \\
28 & 11,3 & 14,74 & 3 \\
30 & 35,2 & 10,43 & 10,5 \\
31 & 31 & 14,12 & 9 \\
32 & 15,4 & 9 & 5,25 \\
\hline
\end{tabular}

Berdasarkan Tabel 5 terdapat 14 pohon yang termasuk pohon cacat yang memiliki diameter batang, tinggi total, dan lebar tajuk yang cukup bervariasi. Diameter batang terbesar terdapat pada pohon nomor 10 yaitu $44,5 \mathrm{~cm}$ kemudian diameter batang terkecil pada nomor 3 yaitu 10,3 cm. Tinggi total pohon tertinggi terdapat pada pohon nomor 12 yaitu 29,33 m, kemudian tinggi total terendah pada pohon nomor 32 yaitu $9 \mathrm{~m}$. Selanjutnya pada lebar tajuk terbesar terdapat pada pohon nomor 30 yaitu 10,5 m sedangkan lebar tajuk terkecil terdapat pada pohon nomor 3 yaitu $0,63 \mathrm{~m}$. 
Dari data lapangan tersebut dapat dijadikan parameter untuk mengetahui hubungan antara diameter batang dengan tinggi total pada pohon cacat. Untuk mengetahui hubungan antara diameter dengan tinggi total pada pohon cacat dapat dilihat pada Tabel 6.

Tabel 6. Nilai Korelasi dan Persamaan Regresi antar Parameter

\begin{tabular}{cccccc} 
Parameter yang dihubungkan & & \multirow{2}{*}{$\mathrm{R}^{2}$} & $\mathrm{a}$ & $\mathrm{b}$ \\
$\mathrm{y}$ & $\mathrm{y}$ & & & \\
\hline \multirow{2}{*}{ Diameter batang } & Tinggi total pohon & 0,0082 & 0,0451 & 14,873 \\
& Lebar tajuk & 0,4171 & 0,2175 & 0,1142 \\
& & & & \\
Tinggi total pohon & Lebar tajuk & 0,00583 & 0,0489 & 5,8335 \\
\hline
\end{tabular}

Pada Tabel 6 terlihat bahwa hubungan antara diameter batang $(\mathrm{x})$ dengan tinggi total pohon $(y)$ memiliki nilai koefisien korelasi $\left(R^{2}\right)=0,0082$, dari hubungan tersebut terlihat nilai a $=$ 0,0451 dan nilai $b=14,873$ yang berarti menunjukkan kedua variabel tersebut bernilai positif hal ini dikarenakan nilai $b$ menunjukkan nilai positif $(+)$. Selanjutnya hubungan antara diameter batang (x) dengan lebar tajuk (y) memiliki nilai koefisien korelasi sebesar $\left(R^{2}\right)=0,4171$, dari hubungan tersebut juga terlihat nilai $a=0,2175$ dan nilai $b=0,1142$ yang berarti menunjukkan kedua variabel tersebut bernilai positif hal ini dikarenakan nilai $b$ menunjukkan nilai positif $(+)$. Sedangkan hubungan antara tinggi total pohon $(\mathrm{x})$ dengan lebar tajuk $(\mathrm{y})$ memiliki nilai korelasi sebesar $\left(\mathrm{R}^{2}\right)=$ 0,00583, hal ini menunjukkan bahwa hubungan tersebut juga terlihat nilai $a=0,0489$ dan nilai $b=$ 5,8335 yang berarti kedua vairabel tersebut bernilai positif hal ini dkarenakan nilai b menyatakan nilai positif $(+)$.

\section{Hubungan Nilai Korelasi dan Persamaan Regresi pada Pohon Cacat.}

Berikut adalah nilai korelasi dan koefisien untuk mengetahui hubungan antara diameter batang pohon dangan tinggi total pohon, diameter batang dengan lebar tajuk, dan tinggi total pohon dengan lebar tajuk pada pohon cacat dapat dilihat pada tabel berikut.

\section{Hubungan diameter batang dengan tinggi total pada pohon cacat}

Berdasarkan hasil penelitian yang telah dilakukan, dapat diketahui hubungan diameter batang dengan tinggi total pohon cacat pada lokasi penelitian. Untuk lebih jelasnya dapat dilihat pada Gambar 7. 
Profil Pohon pada jenis Litsea spp. di Hutan Pendidikan

(Fajriansyah", Rita Diana, \& Paulus Matius)

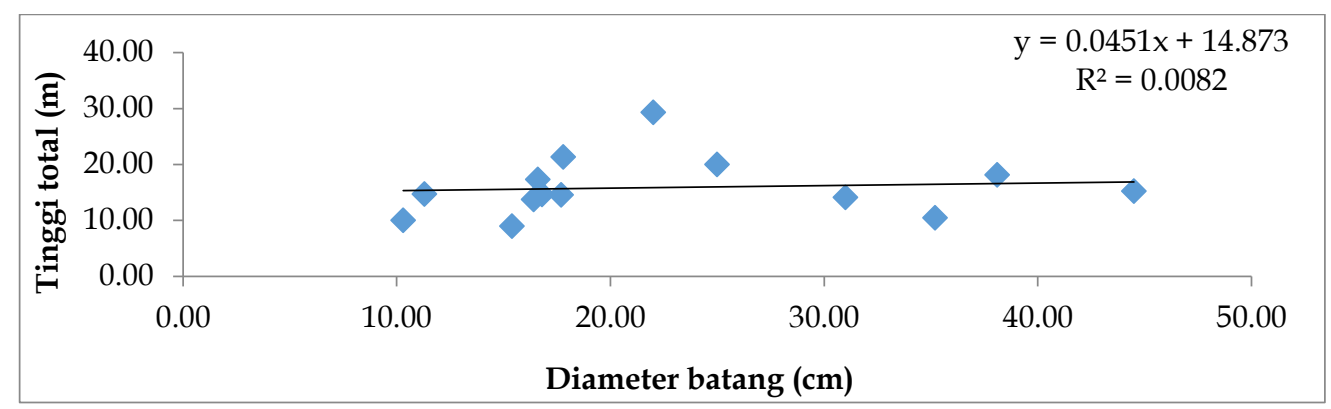

Gambar 7. Grafik hubungan diameter batang dengan tinggi total pohon cacat

Gambar 7 memperlihatkan bentuk persamaan nilai koefisien korelasi sebagai berikut $\mathrm{y}=$ $0,0451 x+14,873$, dalam hal ini berarti, nilai $b=0,0451 x$ menunjukkan bahwa terjadi hubungan positif, artinya semakin besar diameter batang maka semakin bear pula tinggi total pohon, sedangkan nilai a $=0,0451$, yang berarti menunjukkan nilai awal perhitungan diameter batang. Kerataan hubungan antara diameter batang $(\mathrm{x})$ dengan tinggi total pohon (y) dinyatakan dengan nilai korelasi $\left(R^{2}\right)=0,0082$ dimana hubungan fungsional variabel tersebut rendah

Hal ini sama dengan penelitian yang dilakukan oleh Diana dkk, (2011) pada jenis. Scorodocarpus borneensis Becc diketahui bentuk persamaannya adalah y $=0,04 x+11,67$ dan diperoleh korelasi $\mathrm{R}^{2}=0,13$ yang sangat rendah, dimana semakin besar diameter batang berkaitan terhadap pertumbuhan tinggi total pohon. Dengan kata lain, parameter diameter batang dengan tinggi total pohon cacat tidak dapat dijadikan indikasi yang sangat kuat dalam memprediksikan pertumbuhan tinggi total pohon.

\section{Hubungan diameter batang dengan lebar tajuk pada pohon cacat}

Berdasarkan hasil penelitian yang telah dilakukan, dapat diketahui hubungan diameter batang dengan lebar tajuk pohon cacat pada lokasi penelitian. Untuk lebih jelasnya dapat dilihat pada Gambar 8.

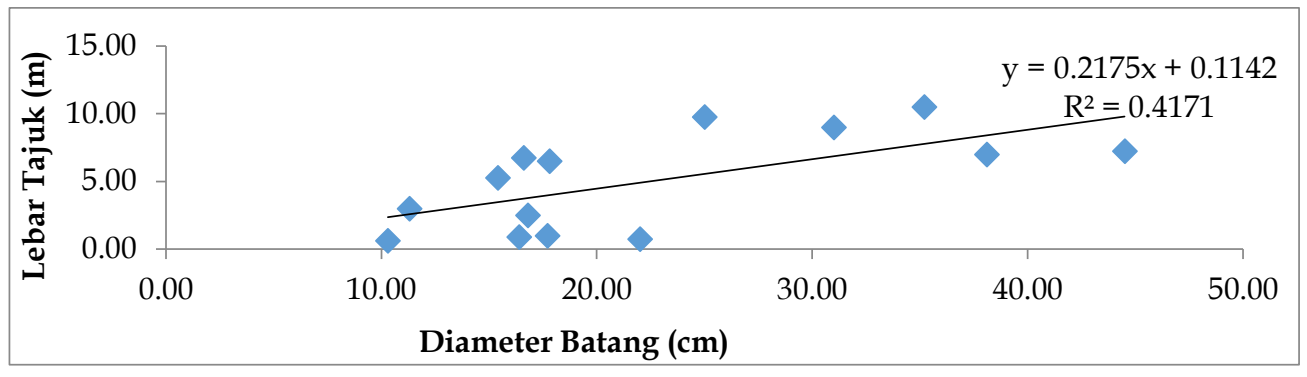

Gambar 8. Grafik hubungan diameter batang dengan lebar tajuk pohon cacat

Gambar 8 memperlihatkan bentuk persamaan nilai koefisien korelasi sebagai berikut $\mathrm{y}=$ $0,2175 x+0,1142$, dalam hal ini berarti, nilai $b=0,2175 x$ menunjukkan bahwa terjadi hubungan yang positif, sedangkan nilai $a=0,1142$ yang berarti menunjukkan nilai awal perhitungan 
diameter batang. Kerataan hubungan antara diameter batang $(\mathrm{x})$ dengan lebar tajuk (y) dinyatakan dengan nilai korelasi $\left(R^{2}\right)=0,4171$ dimana hubungan fungsional variabel tersebut sedang.

Penelitian ini sejalan dengan penelitian yang dilakukan oleh Diana dkk (2011) pada jenis Scorodocarpus borneensis Becc. Parameter diameter batang dengan lebar tajuk diperoleh koleratif positif namun rendah dengan nilai korelasi yang diperoleh yaitu $R^{2}=0,23$, dengan bentuk persamaannya $y=0,03 x+5,84$. Hal ini berarti bahwa semakin besar diameter tidak selalu berkaitan dengan lebar tajuk. Artinya, parameter diameter batang dengan lebar tajuk dapat dijadikan indikasi yang kuat dalam memperkirakan pertambahan lebar tajuk pohon.

\section{Hubungan tinggi total pohon dengan lebar tajuk pada pohon cacat.}

Berdasarkan hasil penelitian yang telah dilakukan, dapat diketahui hubungan diameter batang dengan lebar tajuk pohon cacat pada lokasi penelitian. Untuk lebih jelasnya dapat dilihat pada Gambar 9.

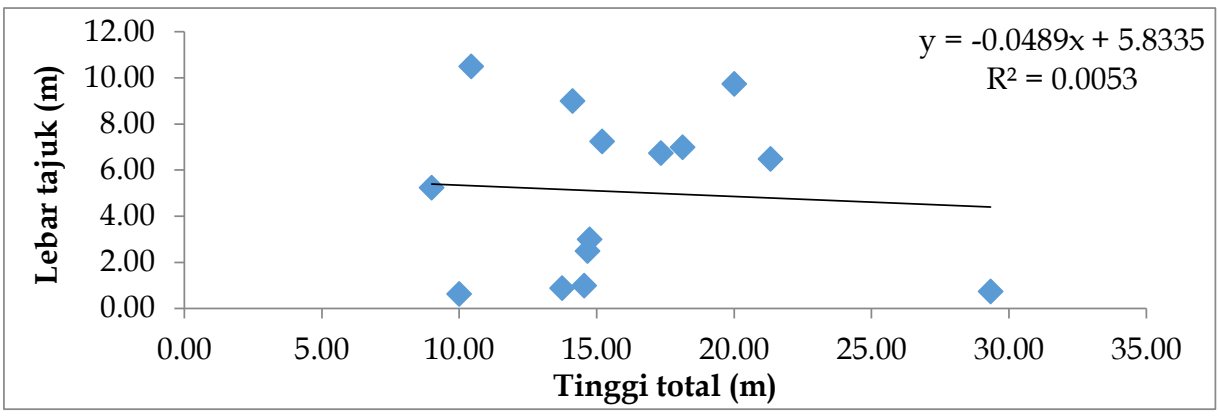

Gambar 9. Grafik hubungan tinggi total pohon dengan lebar tajuk pada pohon cacat.

Gambar 9 memperlihatkan bentuk persamaan nilai koefisien korelasi sebagai berikut y = $0,0489 x+5,8335$, dalam hal ini berarti, nilai $b=-0,0489 x$ menunjukkan bahwa terjadi hubungan yang positif,artinya semakin besar diameter batang semakin besar pula tinggi total pohon. Sedangkan nilai $\mathrm{a}=5,8335$ yang berarti menunjukkan nilai awal perghitungan diameter batang, keeratan hubungan antara tinggi total pohon dengan lebar tajuk (y) dengan nilai korelasi $\left(\mathrm{R}^{2}\right)$ $=0,0053$ dimana hubungan fungsional variabel tersebut sangat rendah. Parameter ini menunukkan bahwa tinggi total pohon tidak dapat dijadikan indikasi yang kuat dalam memperkirakan pertambahan lebar tajuk pohon pada pohon.

Penelitian ini sejalan dengan penelitian yang dilakukan oleh Diana dkk (2011) pada jenis Scorodocarpus borneensis Becc. Parameter tinggi total pohon dengan lebar tajuk diperoleh korelatif positif namun rendah dengan nilai korelasi yang diperoleh yaitu $R^{2}=0,22$, dengan bentuk persamaannya $y=0,08 x+5,76$. hal ini berarti bahwa semakin tinggi, pohon tidak selalu berkaitan terhadap lebar tajuk. Artinya, parameter diameter batang dengan lebar tajuk tidak dapat dijadikan indikasi yang kuat dalam memperkirakan pertambahan lebar tajuk pohon. 
Profil Pohon pada jenis Litsea spp. di Hutan Pendidikan

(Fajriansyah", Rita Diana, \& Paulus Matius)

\section{KESIMPULAN}

Secara umum kondisi fisik kesehatan pohon Litsea spp. pada lokasi penelitian tergolong dalam kondisi sehat. Diameter batang Pohon Litsea spp. jika dikaitkan dengan tinggi pohon dan lebar tajuk memiliki hubungan kolerasi sedang hal ini mengindikasikan bahwa diameter pohon tidak memiliki hubungan terhadap tinggi pohon dan lebar tajuk pada pohon Litsea spp. Kondisi serupa juga terjadi pada hubungan kolerasi antara tinggi pohon yang juga memiliki hubungan kolerasi sedang sehingga mengindikasikan tinggi pohon tidak memperngaruhi lebar tajuk.

\section{DAFTAR PUSTAKA}

Badan Pengelola Hutan Pendidikan. 2018. Tata Hutan Pendidikan Fahutan Unmul (HPFU) Tahun 2018-2026). Pemerintah Provinsi Kalimantan Timur Kotamadya Samarinda.

Cronquist, A. 1981. An Integrated System of Classification of Flowering Plants. Colombia Univesuty Press. New York

Indriyanto. 2008. Ekologi Hutan. PT Bumi Aksara. Jakarta.

Kostemans, A.1957. communication of The Forest Research Institute Indonesia. Balai Penyelidikan Kehutanan. Bogor

Kuspradini, dkk. 2018. Potensi Tumbuhan Genus Litsea. Mulawarman University Press. Samarinda

Park C, Junaedi A, Lee M, Lee Y. 2010. Biological resources potential and the recent state of international cooperation in Indonesia. Interdisciplinary Bio Central 2 (11): 1-10

Putri, P.K, dkk. 2015. Budidaya Kilemo (Litsea cubeba) Untuk Mendukung Kelestarian Tanaman Dataran Tinggi Penghasil Atsiri. Balai Penelitian Teknologi Perbenihan. Badan Litbang Kehutanan, Bogor. Prosiding Nasional MBI. Volume 1, Nomor 6, September 2015 Halaman: 1487-1491.

Rocky FR, Takeda J, Kawet L, Eung-Cheol Lee. 2008. A study on utilization and maintenance of local resources at Woloan in sub-district and warembungan village,north sulawesi province, indonesia with special reference toforest use and management. Bull Fac Agr Saga Univ 93: 2753 .

Sugiyono. 2010. Statistika untuk Penelitian. Alfabeta. Bandung

Whitemore, T.C. 1984. Tropical Rain Forest of the far East. Clarendon Press, Oxford.

Yunita L. 2016. Pendugaan Cadangan Karbon Tegakan Meranti (Shorealeprosula) Di Hutan Alam Pada Area Silin Pt Inhutani Ii Pulau Laut Kalimantan Selatan. Jurnal Hutan Tropis Volume 4 No. 2, Edisi Juli 2016, Hal 187-188. 